\title{
Association of radioactivity of the monazite sands of the beaches of the Guarapari city with the presence of parasites of zoonotic potential
}

\author{
Associação da radioatividade da areia monazítica das praias \\ do município de Guarapari com a presença de parasitos de \\ potencial zoonótico
}

\author{
Gabriel Ricardo de Souza Lima', Maria Larissa Bitencourt Vidal², Ygor Henrique da Silva', André Garcia Oliveira', \\ Isabella Vilhena Freire Martins ${ }^{3^{*}} \&$ Daniel Calheiros Silva ${ }^{4}$ \\ 'Veterinarian, Laboratório de Parasitologia (LP), Departamento de Medicina Veterinária (DMV), Centro de Ciências Agrárias e \\ Engenharias (CCAE), Universidade Federal do Espírito Santo (UFES), Alegre, ES, Brasil. \\ 2 Veterinarian, MSc., LP, DMV, CCAE, UFES, Alegre, ES, Brasil. \\ ${ }^{3}$ Veterinarian, DSC., LP, DMV, CCAE, UFES, Alegre, ES, Brasil. \\ ${ }^{4}$ Physicist, MSc., Departamento de Física, Centro de Ciências Exatas, Naturais e da Saúde, UFES, Alegre, ES, Brasil.
}

\begin{abstract}
The city of Guarapari, known as "Healthy City", has as its main tourist attraction radioactive sands known as monazite sands. There are many studies aimed at quantifying radiation, but little is known about an influence of radiation levels on the life cycle of parasites with zoonotic potential, since many owners take their animals to beaches facilitating a maintenance of their cycle. The objective of the present work was to evaluate the association of the sand radiation of the beaches of the municipality of Guarapari and the presence of eggs and larvae of zoonotic potential parasites. To determine the influence of the radiation on the parasites, sand and faeces samples were collected from the beaches of Praia do Morro, Areia Preta, Castanheiras, Setiba and Santa Mônica, and how to analyze, use the simple centrifugal-flotation technique. The beaches of the present study were classified as low, medium and high radioactivity according to the dose limits that a human being can receive. The samples of sand and faeces were grouped according to a classification of the beaches where they were collected as samples. After obtaining the result, a Chi-square statistical test was performed at a significance level of 95\% to evaluate an association between radiation classes and parasite presence. In general, monazitic sands have an influence on the maintenance of the cycle of zoonotic parasites found in beach sand, their correlation being inversely proportional.
\end{abstract}

Keywords: environmental contamination, geohelminths, radioactive sands.

\section{Resumo}

O município de Guarapari, balneário conhecido por "Cidade Saúde", possui como principal atrativo turístico as areias radioativas conhecidas como areias monazíticas. Há muitos estudos direcionados a quantificação da radiação, mas pouco se sabe sobre a influência dos níveis de radiação sobre o ciclo de vida dos parasitos com potencial zoonótico, uma vez que muitos proprietários levam seus animais as praias, facilitando a manutenção desses ciclos. O objetivo deste trabalho foi avaliar a associação da radiação da areia monazítica das praias do município de Guarapari e a presença de ovos e larvas de parasitos de potencial zoonótico. Para determinar a influência da radiação sobre os parasitos, coletou-se amostras da Praia do Morro, Areia Preta, Castanheiras, Setiba e Santa Mônica, a partir de areias e de fezes, para a análise utilizou a técnica de centrifugo-flutuação simples. As praias deste estudo foram classificadas em baixa, média e alta radioatividade de acordo com as doses limites que um ser humano pode receber. As amostras de areia e fezes foram agrupadas de acordo com a classificação das praias onde foram recolhidas as amostras. Após obtenção do resultado, foi feito teste estatístico Qui-quadrado a um nível de significância de 95\% para avaliar a associação entre as classes de radiação e a presença dos parasitos. Em geral, as areias monazíticas têm influência na manutenção do ciclo de parasitas zoonóticos encontrados na areia da praia, sendo sua correlação inversamente proporcional.

Palavras-chave: contaminação ambiental, geohelmintos, areias radioativas.
How to cite: Lima, G. R. S., Vidal, M. L. B., Silva, Y. H., Oliveira, A. G., Martins, I. V. F., \& Silva, D. C. (2021). Association of radioactivity of themonazite sands of the beaches of the Guarapari city with the presence of parasites of zoonotic potential. Brazilian Journal of Veterinary Medicine, 43 e000920. https://doi.org/10.29374/2527-2179 bjvm000920

Received: September 6, 2020. Accepted: January 15, 2021

\section{*Correspondence}

Maria Larissa Bitencourt Vidal Universidade Federal do Espírito Santo - UFES Alto Universitário, s/no, Guararema CEP 29500-000 - Alegre (ES), Brasil E-mail: larissabvidal@gmail.com 


\section{Introduction}

Guarapari is a municipality that belongs to the Metropolitan Region of Vitória, in the state of Espírito Santo, Brazil, and during high season it receives more than 500 thousand tourists, a quantity that is attracted by the beauty of the beaches as well as by the medicinal power of the municipality's monazitic sands (Guarapari, 2014).

Monazite is a reddish-brown phosphate, and the sands that have this phosphate have a striking characteristic of having a dark tone due to the presence of other minerals such as magnetite, imenite and rutile (Okuno et al., 1982).

Since sand is an environment in which many agents have been found as parasites, there is a growing concern with the contamination of spas because these areas are related to recreation. Disease outbreaks are closely linked to the peak season, the number of bathers increasing as well as the presence of domestic animals (Barros \& Brigitte, 2014).

If we consider the total population of animals in Brazil, secondly Brazilian Institute of Geography and Statistics, we have that in 2013, it was estimated that 43.3\% of Brazilian households had at least one dog and $17.7 \%$ at least one cat, making the total 28.9 million and 11.5 million households, respectively, with the presence of these animals (Instituto Brasileiro de Geografia e Estatística, 2013).

Animals, especially stray animals, can transmit parasitic and infectious diseases (Alves et al., 2013), playing an important epidemiological role in the contamination of public places and in the spread of infections by various types of parasites.

The coexistence between humans and animals is not limited to just the home, but there is also the sharing of recreation places for humans, where these animals can defecate and transmit parasitic zoonoses. This transmission cycle is associated with the elimination of helminth eggs and gastrointestinal protozoan oocysts by the faeces of dogs or cats, and several agents have zoonotic potential, such as Ancylostoma braziliense and A. caninum responsible for Cutaneous Larva Migrans (CLM), Toxocara canis and T. cati, potentially cause Visceral Larva Migrans (VLM), in addition to other helminths such as Dipylidium caninum, which in their erratic cycles can parasitize humans (Corrêa \& Moreira, 1996).

So true is this concern that in the municipality of Guarapari there is a law number 3804/2014 which in article17, paragraph 2, prohibits the transit of dogs and cats along the shore of the beaches, this concern being so clear that in article 1 the executive power of the municipality is committed to the population control of domestic animals to prevent zoonoses of interest in public health and other accidents and aggressions caused by animals (Guarapari, 2014).

There are reports in the literature of the benefits and harms of radiation emitted by monazitic sands on human health (Nascimento Júnior et al., 2011), but it is not known about the influence of this radiation on the parasites that can be found on the beach sand. Living beings are not equally sensitive to radiation (Okuno et al., 1982), indicating that these parasites may or may not be sensitive to radioactivity.

It is worth mentioning that there are studies whose research target was the beaches of the coast of Espírito Santo, both measuring radiation levels (Barros \& Brigitte, 2014) and the presence of parasites (Silva et al., 2015), but there is no correlation between the results obtained. Another important factor is that the sands of the beaches of Guarapari have higher radiation counts when compared to the other beaches of greater Vitória in Espírito Santo (Barros \& Brigitte, 2014), thus allowing the evaluation of the activity of these parasites with higher doses of radiation.

The objective of this study was to evaluate the association of radioactivity of monazitic sand from the beaches of the city of Guarapari with the presence of parasites of zoonotic potential found in the sand and in the faeces present in the sand. Diagnose which are the main geohelminths and parasites present in the sand of the beaches of this municipality, allowing the population to orient themselves on the benefits and potential risks of monazitic sands, with emphasis on the control and prevention of diseases of their pets, since they are not treated, can be potential transmitters of diseases to humans.

\section{Material and methods}

The collections of sand and faeces were carried out on the beaches of Santa Mônica, Morro Beach, Areia Preta, Castanheiras in the municipality of Guarapari - ES from October 2016 to June 2017 and were evaluated in the Parasitology laboratory of the Veterinary Hospital of the University of Espírito Santo and in the Biology Laboratory of Colégio Maxime Centro Educacional 
in Guarapari. This research was carried out with authorization from the Animal Use Ethics Commission (CEUA-UFES) under number 74/2016.

At each collection, 15 sand samples were always collected at the same point, with at least 4 collections being made on each beach. For the places where animal faeces were found, the collection was done according to the method of Matesco et al. adapted (2006), which was collected in five points next to them: one below the faeces and another four around the faeces at a distance of $30 \mathrm{~cm}$ forming vertices of a quadrilateral.

Only for Santa Mônica beach, as it was not analyzed in the study by Calheiro et al. (2016) and Vasconcelos et al. (2013), in the collection of October 1, 2016, the radiation quantification was done according to the methodology of Calheiro et al. (2016) who used a Geiger Muller counter and next to it a cyclocomputer traced the collection route, as well as marked the collection points for later assembly of a route on a graph correlating the peak radiation point. With the highest effective dose value obtained, the equivalent annual dose was projected, multiplying the value obtained in $\mu \mathrm{Sv}$ h-1 by the number of hours in a year (8760h), thus obtaining the equivalent annual dose for this beach.

The radioactivity of the beaches of Castanheiras and Areia Preta, the equivalent dose value (mSv y-1) obtained through the projections of Calheiro et al. (2016) was used and for the beaches of Setiba and Morro Beach the absorbed doses obtained by Vasconcelos et al. (2013) were used.

To classify radioactivity as low, medium and high dose equivalents, the minimum annual dose limits for humans were used, with doses that do not exceed $2.8 \mathrm{mSv}$ y-1 being considered low, which is the limit for human non-health professionals (International Atomic Energy Agency, 2004). For the average classification, there were beaches whose annual dose was between $2.8 \mathrm{mSv}$ y-1 to $50 \mathrm{mSv}$ y-1, since the last value is the maximum dose that a health professional can receive (Brasil, 1998). For the high classification, those beaches that exceed the limit dose for health professionals were considered.

The coproparasitological analyzes of the samples wereadapted according to the work of Pedrassani etal. (2008) in which using the simple centrifugal-flotation technique or Sheather's method using $2 \mathrm{~g}$ of faeces and $10 \mathrm{~g}$ of sand. They were homogenized in $15 \mathrm{~mL}$ of water in Falcon tubes for centrifuges and filtered through gauze sieves. These, after filtration, were centrifuged for 10 minutes at $2500 \mathrm{rpm}$.

After centrifugation, the supernatant was discarded and $15 \mathrm{~mL}$ of saturated sugar solution was added, which were also centrifuged for 10 minutes at 2500 rpm. After this step, it was completed with saturated sugar solution, until a meniscus was formed at the edges of the tube. Finally, coverslips were placed on these and after 10 minutes they were analyzed under a microscope.

A descriptive analysis of the parasites observed for each beach was carried out and grouped quantitatively according to the radioactivity categories of the beaches (low, medium and high). For the statistical analysis of the data, the Chi-square test $\left(\mathrm{X}^{2}\right)$ was used to assess the association between the effect of radiation and the presence of parasites in the samples of sand and faeces, using $\mathrm{P}<0.05$.

\section{Results}

The equivalent doses in $\mu$ Sv.h-1 obtained at Santa Mônica beach in the collection of October 1, 2016 are shown in Figure 1.

Morro beach, Setiba, Santa Mônica, Castanheiras and Areia Preta were classified according to the limit of annual dose of radioactivity that a human being can receive in mSvy-1 being considered low the beach that do not exceed $2.8 \mathrm{mSv}$.y-1, high those above $50 \mathrm{mSv} . \mathrm{y}-1$ and average those between these values, as these are the limits that human beings can receive from annual radioactivity.

The classification of the samples defined that the beaches of Morro beach and Setiba had low radioactivity. The beaches of Santa Mônica and Castanheiras were considered to have medium radioactivity and the high coefficient was considered only for the Areia Preta beach (Table 1).

The total amount of sample collected from all beaches was 330 of sand and 29 of faeces, making a total of 359 samples analyzed. Of these 330 collected sand samples, 28 (8.48\%) were positive for the presence of parasites, and 4.24\% positive for Strongyloidea eggs, 2.73\% for Ancylostoma spp. Larvae, $1.21 \%$ for Ascarididae eggs and 0.3\% for the D. caninum ovigerous capsule, as shown in Table 2 .

Table 3 shows the number of positive and negative samples according to the coefficient of each beach. Evidencing that there were more samples extracted from sand, faeces present in the 


\section{Radiation measurement of October 1,2016 at Santa Mônica beach, Guarapari, Espirito Santo}

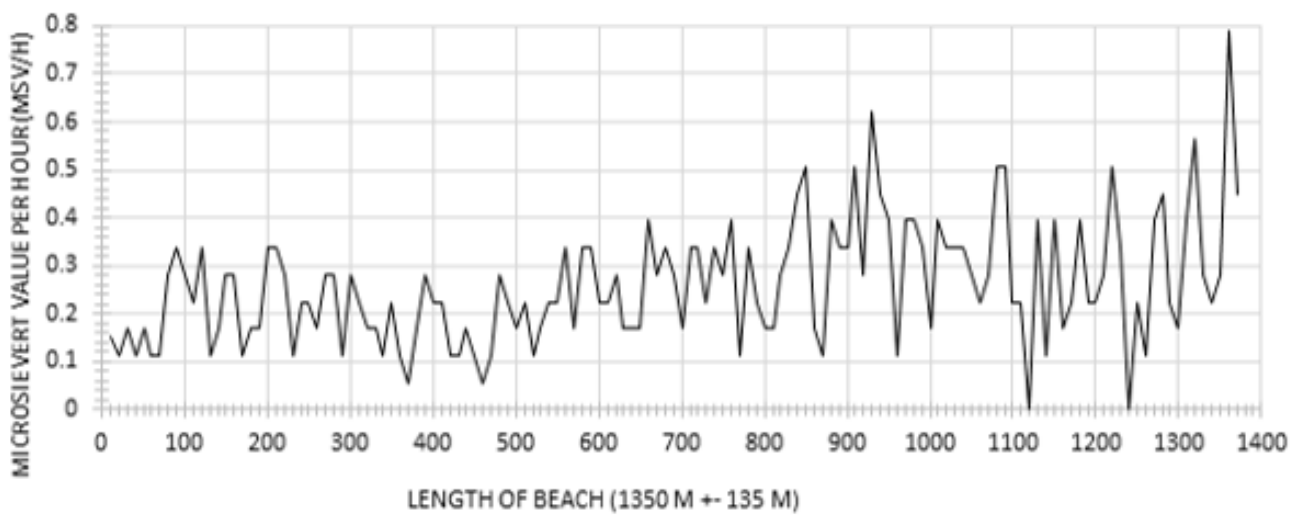

Figure 1. Measurement of radiation in microsievert per hour ( $\mu$ Sv.h-1) on October 1, 2016 at Santa Mônica beach, Guarapari, ES. The measured stretch corresponds to 1350 meters, adopting 10\% of uncertainty given by the computer cycle to more or less corresponding to 135 meters of uncertainty.

Table 1. Beach classification according to the maximum annual dose that a human being can receive in mSv.y-1.

\begin{tabular}{lcc}
\hline \multicolumn{1}{c}{ Beach } & Value in miliSievert $\left(\mathrm{mSv}^{\mathbf{1}}{ }^{\mathbf{2}}\right.$ & Classification \\
\hline Morro Beach* $^{*}$ & 0.022 & Low \\
Setiba Beach* & 0.023 & Low \\
Santa Mônica & 6.81 & Medium \\
Castanheiras** & 49 & Medium \\
Areia Preta** $^{* *}$ & 290 & Highfont \\
\hline
\end{tabular}

Source: ${ }^{*}$ (Vasconcelos et al., 2013); **(Calheiro et al., 2016).

Table 2. Parasites found in samples of positive sands and faeces on the beaches of Santa Mônica, Praia do Morro, Setiba Beach, Castanheiras Beach and Areia Preta Beach.

\begin{tabular}{|c|c|c|c|c|c|c|c|c|c|c|c|}
\hline \multirow[t]{2}{*}{ Parasites/Beaches } & \multicolumn{2}{|c|}{$\begin{array}{c}\text { Santa } \\
\text { Mônica }\end{array}$} & \multicolumn{2}{|c|}{$\begin{array}{l}\text { Morro } \\
\text { Beach }\end{array}$} & \multicolumn{2}{|c|}{ Setiba } & \multicolumn{2}{|c|}{ Castanheiras } & \multicolumn{2}{|c|}{$\begin{array}{l}\text { Areia } \\
\text { Preta }\end{array}$} & \multirow[t]{2}{*}{ Total } \\
\hline & $\mathrm{S}$ & $\mathbf{F}$ & $\mathrm{S}$ & $\mathbf{F}$ & $S$ & $\mathbf{F}$ & $\mathbf{S}$ & $\mathbf{F}$ & $S$ & $\mathbf{F}$ & \\
\hline Ovigera capsule of Dipilidium caninum & 1 & 0 & 0 & 0 & 0 & 0 & 0 & 0 & 0 & 0 & 1 \\
\hline Eggs of Strongyloidea & 7 & 3 & 1 & 0 & 3 & 0 & 3 & 1 & 0 & 3 & 21 \\
\hline Larvae of Ancylostoma spp. & 6 & 4 & $\mathrm{O}$ & 0 & 2 & 0 & 1 & O & 0 & 0 & 13 \\
\hline Eggs of Ascarididae & 0 & 1 & 0 & 0 & 2 & 0 & 2 & 1 & 0 & 0 & 6 \\
\hline Eggs of Trichuris spp. & 0 & 1 & 0 & O & 0 & 1 & O & 0 & 0 & 0 & 2 \\
\hline Total & 14 & 9 & 1 & 0 & 7 & 1 & 6 & 2 & 0 & 3 & 43 \\
\hline
\end{tabular}

$\mathrm{S}=$ Sand; $\mathrm{F}=$ Faeces

Table 3. Number of positive and negative samples for parasites with zoonotic potential observed in the sands and faeces of Guarapari beaches with low, medium and high radioactivity.

\begin{tabular}{|c|c|c|c|c|}
\hline \multirow{2}{*}{ Classification } & \multicolumn{2}{|c|}{ Sand } & \multicolumn{2}{|c|}{ Faeces } \\
\hline & Positive & Negative & Positive & Negative \\
\hline $\begin{array}{l}\text { Low radiation } \\
\text { (Praia do Morro/ Setiba) }\end{array}$ & 8 & 112 & 1 & 1 \\
\hline $\begin{array}{l}\text { Medium radiation } \\
\text { (Santa Mônica/ Castanheira) }\end{array}$ & 15 & 120 & 9 & 16 \\
\hline $\begin{array}{l}\text { High radiation } \\
\text { (Areia preta) }\end{array}$ & 0 & 75 & 2 & 0 \\
\hline
\end{tabular}


sand, making a greater number of positives, moreover, the beaches that most yielded positive samples were those of medium radiation, then the one of low radiation and finally those of high radiation. radiation, which presented few positive results.

\section{Discussion}

The average value of the effective dose of Santa Mônica beach on October 1, 2016 was $0.26 \mu$ Sv.h-1, with a standard deviation of 0.127 upwards or downwards. It is noticeable that the radiometric level of this beach is very low, with a peak of $0.789 \mu$ Sv h-1, not exceeding $1 \mu$ Sv h-1, which possibly indicates that these values were low due to the small amount of monazitic sand present on this beach, as well as at Bacutia beach, whose average value found by Calheiro et al. (2016) was from 0.16 to $0.24 \mu$ Sv.h-1 between the months of March to August.

The Santa Mônica beach, compared with the results of Calheiro et al. (2016), reached equivalent dose values close to the Bacutia beach. It can be inferred that these values were close due to the low amount of monazitic sand in these sands, as it was possible to observe that on this beach, during the collections, the absence of dark tone sands, characteristic of monazitic sand due to the presence of monazite associated with other minerals (Okuno et al., 1982).

For this beach, in this collection, the value of greater radioactivity found in Santa Monica (0.789 $\mu$ Sv.h-1) was multiplied by the number of hours per year (8760h), we have the equivalent annual dose in mSv.y-1 (Calheiro et al., 2016) which was $6.91 \mathrm{mSv}$ y-1, as it was considered that the highest radiation value found on the beach was constant during the year, a period that has 8760 hours.

Another factor for these beaches to have these amounts of radiation is the distance from the Areia Preta beach, since both Bacutia and Santa Mônica have reasonable distance that prevent the movements of the tides from taking the monazitic sands to these beaches, because the tide causes radioactive sand to move from one place to another (Calheiro et al., 2016).

As for the presence of parasites in the sands of the municipality of Guarapari, there was a higher prevalence of parasites eggs and larvae, in sand samples than in faeces, of the 330 sand samples 8.48\% were positive, being that in their majority Strongyloidea eggs (4.24\%), Ancylostoma spp. larvae, Ascarididae eggs (1.21\%) and D. caninum ovigerous capsules, compared to other studies that evaluated the beaches of Camburi, Ilha do Boi, Curva da Jurema and Praia do Canto, in Vitória-ES, it was not observed in the same way, positive samples were found only for Ascarididae eggs and Strongyloidea eggs were not found (Silva et al., 2015).

In the present work it was possible to verify that from the samples there was environmental contamination through faeces and sand with greater representation the superfamily Strongyloidea that also includes the genus Ancylostoma, since of the 29 samples of faeces collected, $41 \%$ were positive, being 24,13\% Strongyloidea eggs were observed, $13.79 \%$ of the samples with Ancylostoma spp. Larvae, 6.89\% for Ascarididae eggs and 6.89\% positive for Trichuris spp. eggs.

No studies were found in the researched literature that verified the relationship of the presence of parasites in animal faeces in the sand or even in the sand of beaches, however, studies have already been done in squares and public places, recently Vidal et al. (2019) verified in Alegre-ES, in the stool samples the presence of 60.7\% for Ancylostoma spp., 24\% Toxocara canis, 8.7\% D. caninum and 1\% Taenia sp. and soil and sand samples, hookworm larvae were found in 33.3\%, corroborating with the present study the higher prevalence of Ancylostoma sp.

While the present study showed only $7 \%$ and $41 \%$ of sand samples and faeces positive for some form of zoonotic parasite, Scaini et al. (2003) out of a total of 237 stool samples analyzed in the main avenues of bathhouse Cassino, in Rio Grande do Sul, 86.1\% were positive for eggs and helminth larvae, demonstrating that different public places are potential contaminants for humans and animals, further determining that in both studies, most of the observed samples were positive for evolutionary forms (eggs and larvae) of Ancylostoma spp.

The prevalence of Ancylostoma spp. in the sands of the beaches studied in Guarapari, climatic conditions can be associated, according to Coelho et al. (2007) there is a higher occurrence of CML in months of greater rainfall, in which the present study developed its assessment in this period and observed the presence of causative helminths. 
The association between the radioactivity of the sands and the parasites found in the sand on the beaches was statistically significant in the Chi-square test at a significance level of 95\%, with a value of $\mathrm{X}^{2}=11, \mathrm{P}=0.004082$.

This explains why the prevalence of $8.49 \%$ is lower compared to that of other authors who obtained, 86.6\%, evaluating other public places (Scaini et al., 2003) 26.6\% (Matesco et al., 2006) and $18.75 \%$ (Silva et al., 2015). The low prevalence of positives can be suggested due to the lack of ionizing radiation from natural radionuclides, which can cause direct damage, ionizing molecules or even altering chemical structures and biological functions of living beings or producing indirect free radials (Hiramoto et al., 1996), changing chemical structures and modifying the DNA molecule (International Atomic Energy Agency, 2004).

It is possible to notice that there is a minimum dose of radiation to interfere with the parasite cycle. In the researched literature, the dosage referring to the prevalent helminths of the present study was not found, but tests found with Toxoplasma gondii were found, indicate that it loses its infectivity at least 550 Gy irradiation (Hiramoto et al., 1996) while in metacercariae Clonorchis spp. and Opisthorchis spp. that infect fish, which cause diseases in humans, are inactivated with $0.15 \mathrm{kGy}$.

Statistically for the Chi-square test at a significance level of $5 \%$, the parasites found in the faeces are not influenced by the radioactivity of the beach sand $\left(\mathrm{X}^{2}=3.193 ; p=0.2026\right)$. There was possibly no statistical difference, as the faeces present more favorable conditions of temperature and humidity in relation to sand, as it was possible to observe the presence of larvae in $13.79 \%$ of the faeces positive for hookworms.

Helminth eggs and larvae can find ideal conditions in the faeces to maintain their cycle, because depending on the species of the host, the fecal cake can remain in its original form for longer times, maintaining humidity for months or years, providing shelter for the larvae until the environment is appropriate for maintaining its cycle (Taylor et al., 2017). This justifies the prevalence of positive stools in the present study (41\%) being close to that of Andrade Júnior et al. (2015) with 51.7\% and 33.9\% of Matesco et al. (2006).

In the literature, studies on the effect of radioactivity of monazitic sands on parasites with zoonotic potential on the parasite cycle are lacking. Even with the positive association of radioactivity in the presence of parasites in the sand, it is possible to observe that they present different behavior in faeces, as observed in the present study.

Thus, it is necessary to raise the population's awareness of the movement of animals and the maintenance of the beach cleaning service, because even though radiation has a cumulative effect on biological tissues (Caruncho, 2011), its effect on parasites present in faeces it was not as significant as those present in the sand.

In addition, other variables are relevant to the interference of the parasite cycles, such as the flow of stray animals that circulate on the beaches, the circulation of people and those that take their pets to the beach. The radiation on a given beach, can cause positive or negative stimuli inversely proportional to the development of parasites.

\section{Conclusion}

The present study found that the main agents verified in the samples of sand and faeces were the larval forms of the parasites Ancylostoma spp., Trichuris spp. and Strongylodeia type eggs and D. caninum egg capsules.

The radiation in the monazitic sands of the beaches of Guarapari has an inversely proportional action to the presence of parasites with zoonotic potential, however, in relation to the mechanisms that occur the interference of the agents, they still need to be elucidated.

\section{Acknowledgements}

This study was carried out in partnership with the Parasitology Laboratories of the Federal University of Espírito Santo and the Biology Laboratory of Colégio Maxime Centro Educacional in Guarapari and supported in part by the Espírito Santo Research Support Foundation (FAPES) and by the Coordination of Improvement of Higher Education Personnel (CAPES). 


\section{Ethics statement}

All informations of Ethic Research Comitee when research envolved human or non-human vertebrate. No vertebrate animals were used in the present study, or any individual, only materials eliminated from them.

\section{Financial support}

No financial support was received in the present work.

\section{Conflict of interests}

No conflict of interest, UFES, responsible for financial support.

\section{Authors' contributions}

LGRS and MLBV - Writing, Review and Editing manuscript. YHS - Development of methodology. AGO - Development of methodology; preparation and writing the initial draft. IVFM - Writing, Review and Editing manuscript; Acquisition of the financial support for the project leading to this publication. DCS - Development of methodology; Application of statistical study data.

\section{Availability of complementary results}

No additional information is available.

The study was carried out Universidade Federal do Espírito Santo - UFES, Alegre, ES, Brasil.

\section{References}

Alves, A. J. S., Guilloux, A. G. A., Zetun, C. B., Polo, G., Braga, G. B., Panachão, L. I., Santos, O., \& Dias, R. A. Abandono de cães na América Latina: revisão de literatura. (2013). Revista de Educação Continuada em Medicina Veterinária eZootecnia do CRMV-SP, 11(2), 34-41. http://www.crmvsp.gov.br/arquivo_midia/revista_educacao_ continuada_vol_11_No_2_2013.pdf

Andrade Júnior, A. L. F., Araújo, K. H. S., \& Medeiros, V. S. (2015). Ocorrência de parasitas com potencial zoonótico em fezes de cães coletadas em vias públicas da cidade de Natal. Revista Humano Ser-UNIFACEX, 1(1), 52-59. https://periodicos.unifacex.com.br/humanoser/article/view/624/143

Barros, L. F., \& Brigitte, R. S. P. (2014). The influence of environmental aspects in the variation of natural radioactivity levels in selected brazilian beach sand samples. In: M. Cessa. Beaches erosion, management practices and environmental implications (pp. 87-113). Nova Science Publishers, Inc.

Brasil, Ministério da Saúde. (1998, 1 de junho). Aprova o Regulamento Técnico que estabelece as diretrizes básicas de proteção radiológica em radiodiagnóstico médico e odontológico, dispõe sobre o uso dos raios-x diagnósticos em todo território nacional e dá outras providências (Portaria MS/SVS no 453). Diário Oficial da República Federativa do Brasil. http://www.conter.gov.br/uploads/legislativo/portaria_453.pdf

Calheiro, D. S., Passamai Junior, J. L., \& Orlando, M. T. D. (2016). Estudo da radiação na areia da praia da Areia Preta. In Anais do VII Encontro Científico de Física Aplicada (pp. 1-4). Blucher Proceedings. http://dx.doi. org/10.5151/phypro-vii-efa-035

Caruncho, M. V. (2011). Efeito da radiação diagnóstica. Revista Brasileira de Medicina de Família e Comunidade, 6(19), 116-117. http://dx.doi.org/10.5712/rbmfc6(19)224.

Coelho, W. A. C., Sakamoto, S. M., Suassuna, A. C. D., Ahid, S. M. M., \& Macedo, R. H. (2007). Larvas de ancilostomatídeos em diferentes ambientes do estado do Rio Grande do Norte. Revista Caatinga, 20(3), 80-82. https://periodicos.ufersa.edu.br/index.php/caatinga/article/view/221

Corrêa, GLB. \& Moreira, WS. (1996). Contaminação do solo por ovos de Ancylostoma spp. Em praças públicas, na cidade de Santa Maria, RS, Brasil. Revista da FZVA, 2/3(1), 18-23.

Guarapari, Prefeitura Municipal. (2014,1 de setembro). Dispõe sobre o controle populacional e bem estar animal, sua posse responsável, vacinação, trânsito em vias públicas, comércio, doação, apreensão, remoção, destinação e dá outras providências (Lein. 3804/2014). Diário Oficial dos Municípios do Espírito Santo. http://www.guarapari.es.gov.br/ portal/index.php/atos-oficiais-semad/leis?download=69:lei-3-804-2014-controle-de-populacao-animal\&start=60

Hiramoto, R. M., Almeida, B. S. V., Cardoso, R. P. A., \& Andrade, H. F. (1996). Effects of ${ }^{60} \mathrm{CO}$ ionizing radiation in the viability and infectivity, detected in vitro in LLC-MK2 cells and in vitro in C57BL/6J mice. Memórias do Instituto Oswaldo Cruz, 91(Suppl.). https://www.ipen.br/biblioteca/cd/inac/1999/PDF/CG14AN.PDF

Instituto Brasileiro de Geografia e Estatística - IBGE. (2013). Pesquisa nacional de saúde: 2013: acesso e utilização dos serviços de saúde, acidentes e violências: Brasil, grandes regiões e unidades da federação 2015 (100 p). https:// www.ibge.gov.br/estatisticas/sociais/saude/9160-pesquisa-nacional-de-saude.html?=\&t=o-que-e 
International Atomic Energy Agency - IAEA. (2004). Radiation, people and the enviroment. IAEA. https://www. iaea.org/sites/default/files/radiation0204.pdf

Matesco, V. C., Mentz, M. B., Rott, M. B., \& Silveira, C. O. (2006). Contaminação sazonal por ovos de helmintos na praia de Ipanema, em Porto Alegre, Rio Grande do Sul, Brasil. Revista de Patologia Tropical, 35(2), $135-141$. http://dx.doi.org/10.5216/rpt.v35i2.1902.

Nascimento Júnior, D. R., Aguiar, V. A. P., \& Giannini, P. C. F. (2011). Minerais pesados das areias praiais de Guarapari (ES): Distribuição, proveniência e fatores de risco à saúde. In Anais do XIII Congresso da Associação Brasileira de Estudos do Quaternário ABEQUA, III Encontro do Quaternário Sulamericano, XIII ABEQUA Congress- The South American Quaternary: Challenges and Perspectives. Armação dos Búzios - RJ. http://www.abequa.org. br/trabalhos/1532_23_06_2011_18_06_08_Daniel_Abequa2011.pdf

Okuno, E., Caldas, I. L., \& Chow, C. (1982). Física para ciências biológicas e biomédicas (490 p.). Halper \& Row do Brasil.

Pedrassani, D., Viera, A. M., \& Thiem, E. M. B. (2008). Contaminação por Toxocara spp. e Ancylostoma spp. em áreas de lazer do município de Canoinhas, SC. Archives of Veterinary Science, 13(2), 110-117. http://dx.doi. org/10.5380/avs.v13i2.12895.

Scaini, C. J., de Toledo, R. N., Lovatel, R., Dionello, M. A., dos Anjos Gatti, F., Susin, L., \& Signorini, V. R. (2003). Contaminação ambiental por ovos e larvas de helmintos em fezes de cães na área central do Balneário Cassino, Rio Grande do Sul. Revista da Sociedade Brasileira de Medicina Tropical, 36(5), 617-619. http://dx.doi. org/10.1590/S0037-86822003000500013. PMid:14576878.

Silva, D. A. M., Moraes, P. R., Abreu, A. L. L., Carvalho, H. L. A., Oliveira, E. L. P., \& Fernandes, F. M. (2015). Análise da contaminação por parasitos caninos de importância zoonótica em práias de Vitória(ES). Revista Científica da FAMINAS, 9(2), 27-41. http://periodicos.faminas.edu.br/index.php/RCFaminas/article/view/325

Taylor, M. A., Coop, R. L., \& Wall, L. (2017). Parasitologia veterinária (4. ed., p. 241). Guanabara Koogan.

Vasconcelos, D. C., Reis, P. A. L., Pereira, C., Oliveira, A. H., Santos, T. O., \& Rocha, Z. (2013). Modelling natural radioactivity in sand beaches of Guarapari, Espírito Santo State, Brazil. World Journal of Nuclear Science and Technology, 3(02), 65-71. http://dx.doi.org/10.4236/wjnst.2013.32011.

Vidal, M. L. B., Azevedo, J. C., Novaes, M. T., \& Martins, I. V. F. (2019). Diagnostic of gastrointestinal helminths in sands and canine feces from public locations in Alegre city, Espírito Santo - Brazil. Brazilian Journal of Veterinary Medicine, 41, 1-5. http://dx.doi.org/10.29374/2527-2179.bjvm104619. 